\title{
CORRECTION
}

\section{Correction: Rare germline variants in DNA repair genes and the angiogenesis pathway predispose prostate cancer patients to develop metastatic disease}

Martina Mijuskovic ${ }^{1}$, Edward J. Saunders ${ }^{1}$, Daniel A. Leongamornlert ${ }^{1}$, Sarah Wakerell ${ }^{1}$, lan Whitmore ${ }^{1}$, Tokhir Dadaev ${ }^{1}$, Clara Cieza-Borrella ${ }^{1}$, Koveela Govindasami ${ }^{1}$, Mark N. Brook ${ }^{1}$, Christopher A. Haiman ${ }^{2}$, David V. Conti ${ }^{2}$, Rosalind A. Eeles ${ }^{1,3}$ and Zsofia Kote-Jarai ${ }^{1}$

British Journal of Cancer (2019) 120:867; https://doi.org/10.1038/s41416-019-0419-4

Correction to: British Journal of Cancer (2018) 119:96-104; https:// doi.org/10.1038/s41416-018-0141-7; http://www.bjcancer.com; published online 19 June 2018

This article was originally published under the standard License to Publish, but has now been made available under a CC BY 4.0 license. The PDF and HTML versions of the paper have been modified accordingly.

\begin{abstract}
Open Access This article is licensed under a Creative Commons Attribution 4.0 International License, which permits use, sharing, adaptation, distribution and reproduction in any medium or format, as long as you give appropriate credit to the original author(s) and the source, provide a link to the Creative Commons license, and indicate if changes were made. The images or other third party material in this article are included in the article's Creative Commons license, unless indicated otherwise in a credit line to the material. If material is not included in the article's Creative Commons license and your intended use is not permitted by statutory regulation or exceeds the permitted use, you will need to obtain permission directly from the copyright holder. To view a copy of this license, visit http://creativecommons. org/licenses/by/4.0/.
\end{abstract}

(c) The Author(s) 2019

\footnotetext{
'Oncogenetics, Division of Genetics and Epidemiology, The Institute of Cancer Research, London SW7 3RP, UK; ${ }^{2}$ Department of Preventive Medicine, Keck School of Medicine, University of Southern California/Norris Comprehensive Cancer Center, Los Angeles, CA 90015, USA and ${ }^{3}$ The Royal Marsden NHS Foundation Trust, London SW3 6J, UK Correspondence: Zsofia Kote-Jarai (zsofia.kote-jarai@icr.ac.uk)

These authors contributed equally as joint first authors: Martina Mijuskovic, Edward J. Saunders.

These authors contributed equally as joint last authors: Rosalind A. Eeles, Zsofia Kote-Jarai.
}

Published online: 06 March 2019 